\title{
The Export Competitiveness of Ghana's Cocoa Industry in West Africa
}

\author{
Alhassan Abukari ${ }^{1} \&$ Tan Cunfeng ${ }^{1}$ \\ 1 Department of Agricultural Economics and Management, College of Finance and Economics, Gansu \\ Agricultural University, Lanzhou, China \\ Correspondence: Tan Cunfeng, College of Finance and Economics, Gansu Agricultural University, Anning \\ District, 730070, Lanzhou, Gansu Province, China. Tel: 86-138-9313-2969. E-mail: cunfengtan@gsau.edu.cn
}

Received: September 16, 2020

Accepted: November 1, 2020

Online Published: February 15, 2021

doi:10.5539/jas.v13n3p 80

URL: https://doi.org/10.5539/jas.v13n3p80

\begin{abstract}
Ghana in the year 1911 became the world's largest exporter of cocoa. However, cocoa export in Ghana nearly came to standstill in the 1970s as a result of the outbreak of swollen shoot disease of cocoa. Ghana since then has not been able to rejuvenate its cocoa export as expected. The years 1999 to 2018 have witnessed a downward trend in the export of cocoa in Ghana. This raises questions of whether the phrase "Ghana is cocoa, and cocoa is Ghana" is still valid. The study attempts to analyze the competitiveness of Ghana's cocoa sector vis-à-vis its neighbors. In doing so, the authors calculate the Revealed Comparative Advantage (RCA) and Revealed Symmetric Comparative Advantage (RSCA) for Ghana to compare with other West African exporters of cocoa and assess the determinants of Ghana's cocoa exports. The authors adopt a regression framework to explore the determinants of cocoa exports. The results revealed that Ghana is highly competitive in the export of cocoa beans. The study attributed this advantage to the quality of the cocoa beans Ghana exports. The results further showed that Ghana's cocoa production volumes and the World consumer price of cocoa beans were the major determinants of the volume of cocoa beans exported in Ghana. The study concluded that although Ghana enjoys a comparative advantage in the export of cocoa beans, Ghana's cocoa production volumes fluctuate thus affecting the volume of cocoa exported. Ghana, therefore, needs to invest in new hybrid climate-smart cocoa cultivation to boost production and export.
\end{abstract}

Keywords: competitiveness, cocoa production, cocoa export, Revealed Comparative Advantage, West Africa

\section{Introduction}

Although the Theobromine bean (Cocoa) is alien to the West African sub-region, the sub-region has assumed the lead role in the production of Cocoa. Approximately $70 \%$ of the world production of cocoa comes from Cote d'Ivoire, Ghana, Nigeria, Cameroon, and Guinea. These countries in the year 2017, contributed about 4,099,568 tons of cocoa out of total world production of 5,201,108 tons led by Cote d'Ivoire and Ghana with $38 \%$ and $17 \%$ respectively (FAOSTAT, 2017).

The International Cocoa Organization (ICCO, 2012) report noted that the West African sub-region accounted for about $80 \%$ of the world cocoa export trade between the period of 2007 and 2017, with Cote d'Ivoire, Ghana, Nigeria, and Cameroon as the major export source points. The export of the cocoa bean remains the readily available means of foreign exchange for Cote d'Ivoire and Ghana in particular (Kolavalli \& Vigneri, 2018).

The cocoa industry in the West African sub-region is highly competitive. This is because these countries seek to enhance food security, mitigate the harm of poverty, and boost their export-based crop cultivation to earn optimum foreign exchange to support growth and development (David, 2013).

In Ghana, the dream and stratagem for revolutionizing the cocoa sector are the dictates of "competitiveness, resilience, and robustness" (The World Bank Group \& Agriculture Global Practice West Africa, 2017). As noted by Van Rooyen and Boonzaaier (2016), the Industry can only be competitive when you manage it, assess it, and analyze it. The research is thus necessitated by the quest to find an answer to the question of whether the cocoa industry of Ghana is highly competitive or not, since cocoa production and export volumes in Ghana, have taken a downwards fluctuating trend in recent years. 
The research thus presents an analysis of the export competitiveness of Ghana's cocoa industry within West Africa, with the objectives of (1) To compare the performance of the cocoa industry in Ghana with the other major cocoa-producing countries in West Africa by analyzing their competitiveness and (2) assess the major determinants of Ghana's cocoa beans export. Understanding the degree and properties of cocoa production and exportation would aid in enhancing the variables that have significant positive impacts, and also draw the attention of the governing body of the cocoa sector, to the variables that work against the competitive urge of Ghana's cocoa industry and thus needs attention (David, 2013). Analyzing the export performance of the sub-sector would help provide information on how efficient and effective policies concerning competitiveness have been so far.

\section{Cocoa Industry of Ghana}

The Theobromine beans (Cocoa beans) are believed first to have been introduced in Ghana by the Dutch, and the Basel missionaries in 1815 and 1857 respectively. However, Tetteh Quarshie a native Ghanaian who is said to have brought the cocoa bean from Fernando Po in 1879 is hailed for the boom of the cocoa beans in Ghana. Ghana and Cocoa are like the opposite sides of the Global Capitalist coin. They are just inseparable (Lundstedt, 2009) Cocoa cultivation is a source of income for some 800,000 farmers and laborers in the six cocoa growing regions in the forest belt of Ghana (Ghana Living Standard Survey, 2014; Kolavalli \& Vigneri, 2018). Poverty levels among cocoa farmers which stood at $60 \%$ in the 1990 s have reduced drastically to $24 \%$ in 2005 (Coulombe \& Wodon, 2007).

According to Kolavalli and Vigneri (2018), Ghana's cocoa industry constitutes about 11.9 percent of the total agricultural value-added and remained the largest export-based crop, which earns for Ghana optimum foreign exchange. They noted further that, the 2011 records of the Bank of Ghana show that export receipt of cocoa beans and products for the first quarter of 2011 closed at $\$ 8600$ million as against $\$ 682.5$ million for the 2010 cropping season. This records a significant 20\% increase in export earnings (Kolavalli \& Vigneri, 2018).

Considering the key role of the cocoa sector in the economy of Ghana, the Ghana COCOBOD is thus seeking to be competitive enough by increasing the productivity of cocoa producers and improve cost efficiency along the cocoa supply chain; remain resilient to challenges and risks related to global cocoa markets, and climate change; and robust by being an industry leader through innovation and differentiation by focusing on high-quality cocoa and niche markets(The World Bank Group \& Agriculture Global Practice West Africa, 2017). This can only be possible when Ghana understands its current export competitiveness and the variables that need to be revised.

\subsection{Governance and Marketing Chain of Cocoa in Ghana}

The whole system and operation of Ghana's cocoa industry is exclusively the preserve of the Government of Ghana. The body responsible for driving and managing the sector is the Ghana Cocoa Board (COCOBOD), which is an agency working under the Ministry of Finance. This institution was established in 1947 with the mandate to monitor and regulate the operations of the cocoa industry in Ghana. The COCOBOD controls the export and internal marketing of cocoa beans, oversees agricultural research, hybridization of seeds, sale of seed to the farmers, quality control, and extension services to the farmers.

Ghana COCOBOD has a monopoly over the purchase and export of cocoa beans. Conversely, the internal purchasing of cocoa beans from producers is carried out by private sector companies who have been registered and given license by the COCOBOD. Presently, the COCOBOD has maintained over twenty-six (26) companies as Licensed Buying Companies (LBC). Per the limited liberalization of the domestic purchase of cocoa beans from farmers, all registered buyers enjoy perfect information and are all required to buy cocoa beans from farmers at the buying centers without engaging in price differentiation. The Ghana COCOBOD through the Cocoa Marketing Company does the export of cocoa beans. All registered buyers purchase cocoa beans from farmers' and sell the cocoa beans to the COCOBOD, at a fixed price determined by the government (COCOBOD, 2012). Indeed the entire marketing system of the cocoa industry in Ghana is strictly control and censored by the COCOBOD (Elmasoeur et al., 2012).

The cocoa value chain in Ghana is extraordinarily complex and subject to dense government involvement. As shown in (Figure 1), The COCOBOD controls the entire system from production, marketing, and Consumption. The belief that the accomplishment of the cocoa industry of Ghana in terms of production and export trade is large as a result of the efforts of the COCOBOD cannot, therefore, be ignored (Osei-Assibey, 2015).

According to Gilbert (2009), the Ghana COCOBOD system and strategies resulted in some significant merits. The limited liberalization system has resulted in farmers receiving instant payment for their products purchased; and also upturns the part of the export price received by farmers. More so, COCOBOD's quality control check 
system is accredited for the premium price cocoa bean from Ghana receives at the world cocoa market. Equally, the forward contracting system, as employed by the COCOBOD has also succeeded in reducing the hazards of price and exchange rate differentials buyers are always confronted with at the buying centers yet such risk is not been borne by farmers either (Gilbert, 2009).

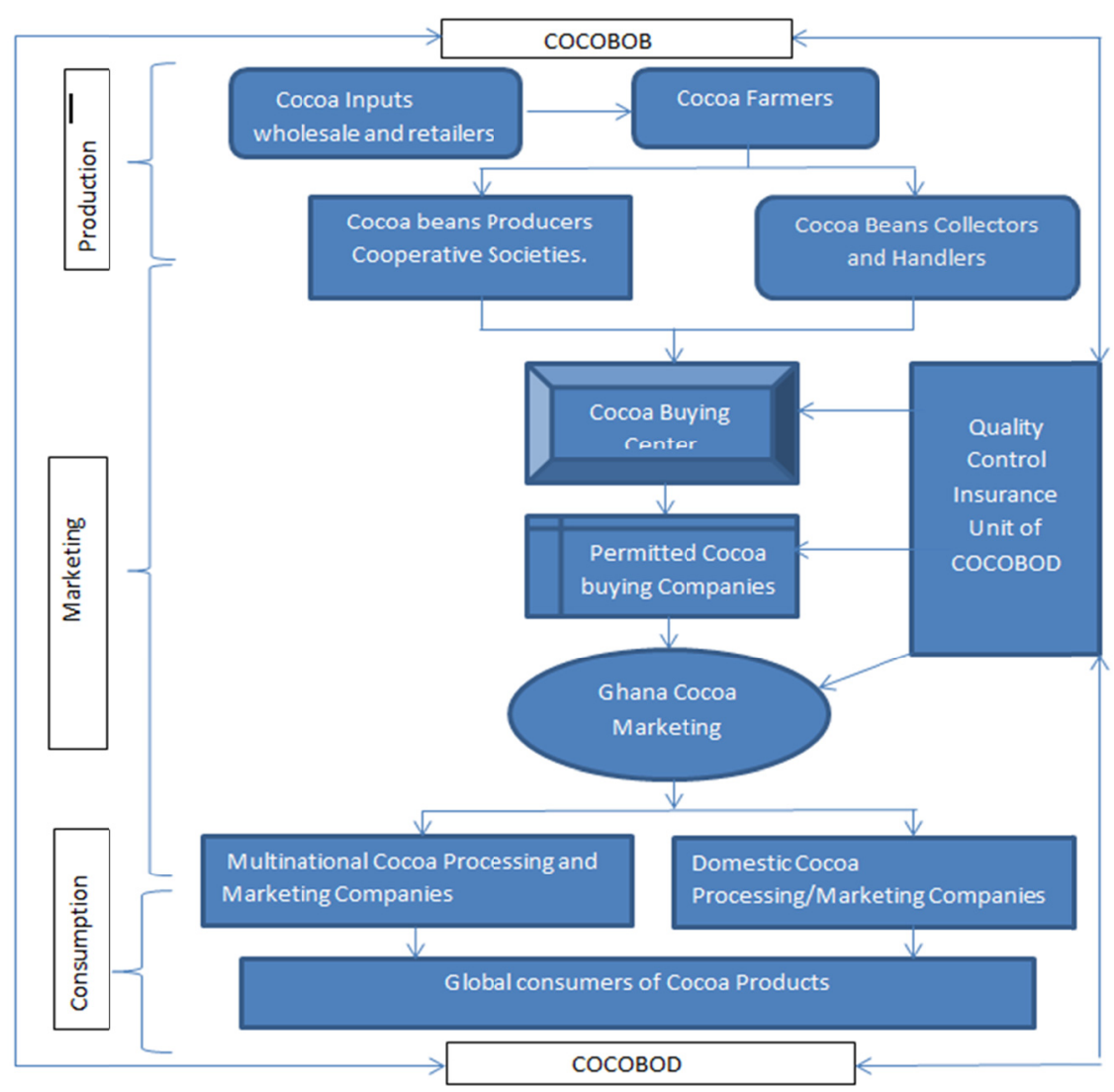

Figure 1. Governance and Supply chain of Cocoa in Ghana

Source: Author's construct with information extracted from Boansi (2013)

\section{Literature Review}

Garelli (2006) reiterated that over 35 million search results always pop up when the concept of competitiveness is searched on the internet. Reiljan (2000) cannot, therefore, be wrong in his reportage that the meaning of the concept of competitiveness has left many economists in a state of confusion, contradictions, and great misunderstanding.

In the works of the Trade and Industry division in the UK (2001), competitiveness connotes the aptitude to create veracious goods and services with excellence, and efficiency. In their viewpoint, customers will be well served meritoriously by a given firm than other firms do.

The OECD (2013) took an extensive approach by defining competitiveness as the notch to which a firm or a nation in perfect market settings, produce goods and services that satisfy international market demands, and also sustain the real income of its people sustainably. This definition stresses the link between exports and standard of living and recognizes four indicators of competitiveness, labour efficiency; real income progression; actual profits and the initial capital ratio of industry; and the global trade rank of an industry.

In a more monetary sense, the World Economic Forum describes competitiveness as "the capacity of a country or company to proportionately earn more capital than its competitors in the global market".

For our study, competitiveness, connotes the ability of a given country or industry to produce and trade in a given product, over and above its competitors in terms, of excellence, revenue generated, and the potential to enhance the growth of the industry. 


\subsection{Analyzing a Country's Competitiveness}

There are no strict jacket means of measuring competitiveness, owing to the complexity of the concept and its varied application at varied circumstances with different variables. However, Siudek and Zawojska (2018) in an optimistic view reiterated that competitiveness can be measured in a three-tier form such as; the macro level which involves competitiveness at the global, national, and regional scales; the meso level which is concerned with competitiveness at the sector and industry level; and the micro-level which deals with competitiveness at the firm or business levels. The method and indices of measuring competitiveness will therefore depend on the level of the analysis.

In the case of our study, the meso level measures are given priority. Although the study determines the export competitiveness of cocoa exporting countries in West Africa, the focus of the analysis is more on the cocoa industries of the various countries than the nations as a whole. Therefore, the macro or country-level measures such as; the Institute for Management Development's World Competitiveness Yearbook (WCY) and the World Economic Forum's Global Competitiveness index despite its commonest, could not be appropriate for this study. This is a result of the fact that such measures, measure the competitiveness of nations, and also with less well established economic theory (Siggel, 2006).

The methods commonly used in analyzing an industry's competitiveness include but not limited to the Revealed Comparative Advantage (RCA) and derived indicators; the Revealed Symmetric Comparative Advantage (RSCA); Relative Trade Advantage (RTA); Export Market Share (EMS); Porter's Competitive Model etc. The study considers the Revealed Comparative Advantage (RCA) and the Revealed Symmetric Comparative Advantage. We choose these indexes because the RCA and RSCA are "easy to compute, widely used in the literature because it gives economic efficiency of industry, expose country's weak and strong export sectors, offer opinions for the conception of policies, and assess country's export competitiveness against some reference group" (Wu \& Lin, 2008; Nicolić et al., 2011; Kuldilok et al., 2013).

\subsection{Revealed Comparative Advantage Index (RCA)}

The Revealed Comparative Advantage (RCA Index) owns its origins from the works of Liesner (1958). However, Balassa (1965) is accredited for the popularization of the RCA index, which eventually became known as 'Balassa's Index. RCA examines the export proportion of a given industry in a given country, relative to the same or similar industry within the country or a given group of countries (Siggel, 2006). The RCA of a country for a given commodity is the proportion of that commodity out of the world total proportion of the commodity (Abei, 2017). The RCA compares a country's share of the world market in a commodity relative to its share of all other traded goods.

Functionally, the RCA index of a given country $\mathrm{X}$ and a given commodity $\mathrm{Y}$ is written as,

$$
\mathrm{RCA}_{\mathrm{XY}}=\left[\frac{\mathrm{Exy}}{\mathrm{Exz}}\right] /\left[\frac{\mathrm{Ewy}}{\mathrm{Ewz}}\right]
$$

where, $\mathrm{RCA}_{\mathrm{xy}}=$ Revealed Comparative Advantage of Country X in Commodity Y; Exy = Country X export value of commodity $\mathrm{Y}$; Exz = Country $\mathrm{X}$ export value of all other commodities; Ewy = World export value of commodity Y; EwZ = World export value of all other commodities.

An RCA value of more than 1 shows a comparative advantage hence highly competitive, whereas an RCA value of less than 1 shows a comparative disadvantage, hence less competitive.

According to Wu and Lin (2008), Nicolić et al. (2011), and Kuldilok et al. (2013), the RCA index is easy to compute, widely used in the literature because it gives economic efficiency of industry, expose country's weak and strong export sectors, offer opinions for the conception of policies, and assess country's export competitiveness against some reference group.

Critics of the RCA index like Yeats (1985) assert that the index is neither cardinal nor ordinal. Lafay (1992), believes that the RCA index completely ignores the impacts of macroeconomic variables. Pitts and Lagnevik (1998) without missing words said the RCA index has no theoretical bases. Dalum et al. (1998) conclude that the index is asymmetric at its neutral value.

\subsection{Revealed Symmetric Comparative Advantage (RSCA)}

The Revealed Symmetric Comparative Advantage was thus propounded by Dalum et al. (1998), as a modification in the RCA index, to ensure symmetry in the RCA value. They noted that the RCA value ought to be symmetric enough to guarantee good econometric analysis since the raw RCA index is not comparable on both sides of unity and also place emphasis on values exceeding 1 (Laursen, 2015). 
Functionally, the RSCA is written as,

$$
\operatorname{RSCA}_{\mathrm{XY}}=\left(\mathrm{RCA}_{\mathrm{XY}}-1\right) /\left(\mathrm{RCA}_{\mathrm{XY}}+1\right)
$$

RSCA value reads from -1 to 1 . Hence a positive RSCA value means comparative advantage whereas a negative RSCA value means a comparative disadvantage.

Laursen (2015), in his work titled "Revealed comparative advantage and the alternatives as measures of international specialization", compared RSCA to other measures of international trade competitiveness used in the literature such as the Michael index, the Chi-Square measure, and the Net Trade Index. They found that the RSCA is the best measure of comparative advantage based on the observation that RSCA better reflects the concept of competitiveness through its focus on a specific area of economic activity within a given country, and also its ability to be applied to patent data. The literature on RSCA as a method of measuring competitiveness is yet to incorporate criticisms of the index since it is a modification of the RCA index; many researchers criticize the RCA and not the RSCA.

RCA and RSCA have been largely used by writers in examining the competitiveness of various industries (Hinloopen \& Van Marrewijk, 2001). In his work on the United States, economy, and Industrial change, Balassa (1977) used the RCA index to assess the competitiveness of US industries. The results were good and show that the US has a comparative advantage in the manufacturing sector.

World Bank (2005) analyzes the export competitiveness of Bosnia and Herzegovina using the RCA index. The findings show that Bosnia and Herzegovina's comparative advantage in EU markets is concerted on primary produce (Miteva-Kacarski, 2018).

Ndubuto et al. (2010) used the RCA and RSCA indexes to analyze the competitiveness of Nigeria's cocoa export. Based on the results, they concluded that Nigeria is very competitive in the export of cocoa for the period of the study. Nigeria's performance they reiterated emanate from the Structural Adjustment Program (SAP) and the attention the government of Nigeria gave to the sector.

David (2013), in his work on the competitiveness and determinants of cocoa exports from Ghana, employed the RCA and RSCA indexes as a model to determine the competitiveness of the cocoa industry of Ghana. His findings concluded that Ghana enjoys a comparative advantage, and highly competitive in the export of cocoa beans and processed cocoa. He attributed the performance of the sector to the domestic processing of cocoa into finished goods, and the continuous and increased support the sector receives from the Government of Ghana.

In his study of the Competitiveness of Indonesia's Cocoa Beans Export in the World Market, Rifin (2013) employed the RCA and RSCA indexes for the analysis. His findings revealed that from the period of 1967-1982, Indonesia had a comparative disadvantage. Growth in comparative advantage was erratic for 1985-1997. The year 2000s however, marked a transformational period where the highest values were achieved.

Startienè and Remeikiene (2014) assess the competitiveness of the Lithuanian industry in global markets using the RCA and RSCA indexes. They found out that Lithuanian food, chemicals, wood, and textile manufacturers were very competitive in the global market between the periods of 2007-2011. They noted that though many sectors were competitive, they were yet to recover fully from the Lithuanian economic crises.

The IMF (2015) employed the RCA Index to assess the competitiveness of Macedonia. The computed RCA index shows that the country is highly competitive in the manufacture of consumer goods, textiles, beverages, and tobacco, with an erratic growth in chemical products (IMF, 2015).

Miteva-Kacarski (2018) reiterated that the Organization for Economic Cooperation and Development (OECD 2013) work on the competitiveness of Central European Free Trade Agreement (CEFTA) member states for the year 2006 with the RCA Index as a measure reveals that CEFTA economies are highly competitive in the export of secondary goods produced with less sophisticated technology.

The RCA index equally provided good results in the works of Ferto and Hubbard 2002; Utkulu and Seymen 2004; Batra and Khan 2005; Jackman et' al 2011; Jafta 2014.

However, the use of these models in their analysis is seen more to the blind side of the observation made by Abei (2017), who noted that to effectively assess the competitiveness of a particular industry of a given country, it is prudent to weigh the industry in question performance with other countries that have the same industry with similar characteristics. This study is unique in its approach as it distinguishes itself from such works wherein the focus of comparison is among the various components of a given industry or against other industries within the same country. This work compares the export performance of the cocoa industry in Ghana with that of the other major cocoa-exporting countries in West Africa. 


\subsection{Determinants of Cocoa Export}

Ngeno (1996), in his work on Kenya's export supply, performed a regression analysis with export supply as a dependent variable and output and exchange rate as independent variables. The results show that Kenya's export supply is significantly and positively determine by output and exchange rate.

Musinguzi and Obwona (2000), on the contrary, regressed export supply on the real exchange rate and lagged export supply and establish that Uganda's export supply is not highly determined by the exchange rate differential.

Gbetnkom and Khan (2002) assessed the predictors of cocoa, coffee, and banana exports from Cameroon; they concluded that the global market price for these products is the key determinant of the export supply of all the crops.

Musila (2004) studied the influence of the common market for Eastern and Southern Africa on Kenya's export. They reiterated that the international market price has demonstrated its prowess as the foremost factor of export supply particularly for primary products.

Kumar et al. (2008), in their study of the determinants of cucumber and Gherkin export from India, regressed Indian export of cucumber and Cherian products as the dependent variable on Indian export price of Gherkin products, total international trade in Cucumber and Gherkin products, and the exchange rate. They indicated that the coefficients for all the variables, except the Indian export price were found highly significant.

Ndubuto et al. (2010) studied the export performance of Nigeria's cocoa industry. In their study, they regressed the export volume of cocoa on the annual volume of cocoa production, the exchange rate of the Nigerian Naira to the US dollars, and the world total volume of cocoa export as independent variables. The results of their analyses had the coefficients of all the variables been statistically significant. They thus concluded that the world export volume of cocoa, Nigeria's total output, and the exchange rate were the major determinants of cocoa export.

Daramola (2011) indicated that Cocoa exports in Nigeria are highly induced by the world price of cocoa. An increase in world prices attracts a high volume of cocoa export from Nigeria. Producer price on the other hand discourages producers from exporting cocoa. They concluded that there is a negative relationship between producer price and cocoa exports, as well as between the exchange rate and export in the country.

David (2013) assessed the enormousness of production of cocoa beans, real domestic producer price of cocoa beans, real-world price of cocoa to real domestic producer price of cocoa ratio, real producer price of cocoa in Côte d'Ivoire (Ivorian Local Currency, FCFA) domestic consumption of cocoa, exchange rate (GHS/US\$), Foreign Direct Investment, and world stocks/grindings ratio as the determinants of cocoa export. The findings revealed that cocoa production, real domestic price, global cocoa price to real producer price ratio of cocoa, and the exchange rate had a significant positive effect on cocoa export. The real domestic price of cocoa for Côte d'Ivoire lagged in domestic consumption and the lagged export of cocoa beans had negative impacts on the export of cocoa.

\section{Methodology}

The study is an analysis of the export competitiveness of Ghana's cocoa beans within West Africa. The study used time-series data (1999 to 2018) extracted from the Food and Agricultural Organization Statistics (FAOSTAT, 2017) for the analysis.

The Revealed Comparative Advantage (RCA) and the Revealed Symmetric Comparative Advantage (RSCA) models were used to analyze the export competitiveness of Ghana's Cocoa industry vis-à-vis other major exporters in West Africa. The bases for which the study employed these indexes is that a greater number of researchers working on competitiveness sees the RCA and RSCA indexes as appropriate and widely used (Hinloopen \& Van Marrewijk, 2001), which has always given good results compared with other measures of competitiveness as seen in the works of Balassa (1977), Ferto and Hubbard (2002), Utkulu and Seymen (2004), Batra and Khan (2005), Nwachukwu et al. (2010), Jackman et al. (2011), Boansi (2013), Jafta (2014), Emilija (2018), etc.

\subsection{The Revealed Comparative Advantage (RCA)}

The RCA of a given product of a country describes the proportion of the product in world trade. The RCA model relates a country's share of the world market in a given product vis-a-vis the share of all other traded goods (Abei, 2017). A country is seen to have a comparative advantage in a given product if the RCA is greater than 1 and a comparative disadvantage if the RCA is less than 1. 
The RCA function of the study is written as,

$$
\mathrm{RCA}_{\mathrm{Ghc}}=\left(\frac{\text { Ghexc }}{\text { Ghexoc }}\right) /\left(\frac{\text { Wexc }}{\text { Wexoc }}\right)
$$

where, $\mathrm{RCA}_{\mathrm{Ghc}}=$ the Revealed Comparative Advantage of Ghana's Cocoa Industry; Ghexc = Ghana's cocoa beans export value for a given year; Ghexoc = Ghana's export value of all other products for a given year; Wexc $=$ World export value of Cocoa beans for a given year; Wexoc $=$ World export value of all other products for a given year.

\subsection{The Revealed Symmetric Comparative Advantage (RSCA)}

The RSCA was introduced by Dalum, Laursen, and Villumsen (1998), as "quasi-logarithmic" modifications of the RCA to guarantee a normal distribution of the RCA index.

The RSCA for the study is written as,

$$
\operatorname{RSCA}_{\mathrm{Ghc}}=\frac{\mathrm{RCA}_{\mathrm{Ghc}}-1}{\mathrm{RCA}_{\mathrm{Ghc}}+1}
$$

The RSCA index ranges from -1 to +1 . The values of RSCA greater than one indicate comparative advantage and negative RSCA values indicate a comparative disadvantage.

In computing the RCA and RSCA for the other countries, we only change the name of the country in question in the equation and substitute in the values of export of cocoa and the values of export for other commodities for the said country and compute.

\subsection{Multiple Linear Regression}

The study also employed multiple linear regressions to assess the strengths of the various predictors of Ghana's, cocoa export. EViews10 software was used to run an Ordinary Least Square test of the various determinants to determine their significance.

The regression was run using the function,

$$
\mathrm{Y}_{\mathrm{Cex}}=\mathrm{c}+\mathrm{Gh}_{\mathrm{cp}}+\mathrm{Gh}_{\mathrm{pp}}+\mathrm{Wcp}+\mathrm{ex}_{(\mathrm{Ghc}-\mathrm{US} \$)+\mathrm{U}}
$$

where, $\mathrm{Y}_{\mathrm{Cex}}=$ Annual volume of cocoa beans exported from Ghana measured in tonnes; $\mathrm{C}=\mathrm{Constant}$; $\mathrm{Gh}_{\mathrm{cp}}=$ Annual volume of cocoa beans produced in Ghana; $\mathrm{Gh}_{\mathrm{pp}}=$ producer price of cocoa in Ghana; Wcp = Annual world consumer price of Cocoa; $\mathrm{ex}_{(\mathrm{Ghc}-\mathrm{US} \$)}=$ Exchange rate from Ghana cedi to US dollars.

\section{Results and Discussion}

\subsection{Export Trade of Ghana's Cocoa Beans}

Ghana's cocoa bean export can best be described as undulating; it goes up and comes down successively as depicted in Figure 1. This is mainly due to poor yields and production. From 1999 to 2003, the export volume of cocoa beans from Ghana remained less than 500,000 metric tonnes. Although the year 2004 saw a boost in the volume of cocoa beans export, the successive years witness a drop recording the lowest volume of export of 281437 metric tonnes for the year 2010. A record high in export quantity for the cocoa subsector of Ghana was recorded in 2014 year; where about 748161MT cocoa beans with a value of US\$2046346 were exported. Unfortunately, the 2015, 2016 years also witnessed a sharp drop from the 2014 year export volume. Ghana lost an export value of US\$160127 between the period of 2014 and 2016 as a result of the drop in export volumes.

Compared with other major exporters of the cocoa beans in West Africa, Ghana has out-competed countries like Guinea, Cameroon, and Nigeria. But Ghana will need to be productive enough to maintain its stand over Nigeria and Cameroon. For Cote d'Ivoire the world's largest producer, it is obvious that Ghana will need to do a triple jump to compete squarely. Although Cote d'Ivoire equally witnessed a drop for the 2008,2010, and 2013 cropping year, it is clear that every drop is followed by a significant increase worthy enough to offset the deficit of the drop. Although Ghana continues to maintain its position as the world's second-largest exporter of cocoa after Cote d'Ivoire, there is a significant nearly over $100 \%$ difference between the export quantities of Cote d'Ivoire and Ghana. The significant differences in the export volume between Ghana and Cote d'Ivoire could be a result of the destruction of cocoa farms in Ghana due to mining activities, smuggling of cocoa from Ghana to Cote d'Ivoire due to the high producer price of cocoa in Cote d'Ivoire and the dysfunctional issues of cocoa management in Ghana. The general outlook of the Ghanaian cocoa export is fluctuating and extra efforts and strategies need to be fashioned out by the Ghana COCOBOD to propel the fortunes of Ghana in competing favorably within the West African Sub-region in terms of cocoa beans export. 


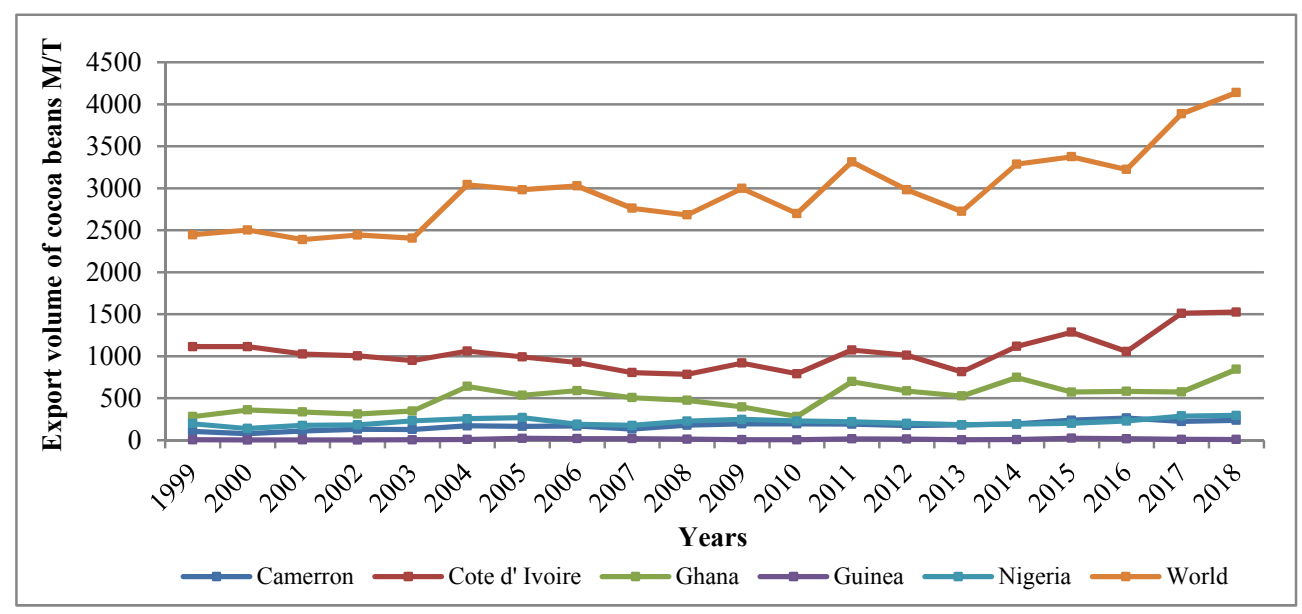

Figure 1. Export volume of Cocoa beans from the major exporters in West Africa and the world from 1999-2018 Source: Author's Construct with Data extracted from FAOSTAT.

\subsection{Revealed Comparative Advantage of Ghana's Cocoa Industry in West Africa}

As shown in Figure 2 and Table 1 above, both the asymmetric RCA and the symmetric RCA (RSCA) shows that the cocoa industry in West Africa is highly competitive. Per the RSCA values, there is an insignificant difference in the competitiveness levels of the countries considered for the study. The Ranks of the countries however in terms of their competitiveness based on both the RSCA and RCA have not changed. Ghana's cocoa industry is ranked first in terms of its competitiveness in the export of cocoa beans between 1999 and 2018. Successively, Ghana has out-competed Cameroon, Cote d' Ivoire, Guinea, and Nigeria. Although pest and disease, the frequent changes in weather and the unproductive nature of the aged cocoa trees in Ghana make production and export undulating. In the year 2013, Ghana out rightly recorded a high comparative advantage value due to the increase in the yield of cocoa in the year 2012, coupled with the increase in the world prices of cocoa. However, Ghana recorded its lowest comparative advantage within the 20 years considered for the study in 2016 year. This decline is not surprising at all because of the vagaries of the weather which constantly affects the yield of cocoa. Although Ghana is the second-largest producer of cocoa beans behind Cote d'Ivoire, The comparatively higher performance of Ghana in total export value of cocoa beans for 1999-2018 over other major exporters of cocoa beans in the West African sub-region is ascribed largely to the quality of the cocoa beans Ghana exports. The fine and good quality export earns for Ghana high export values over and above the other major producers. Also, the increasing government support to farmers and the opening-up of the domestic market to competition through partial liberalization of internal marketing are worthy commended for the comparative advantage of Ghana's cocoa beans export within the West African sub-region.

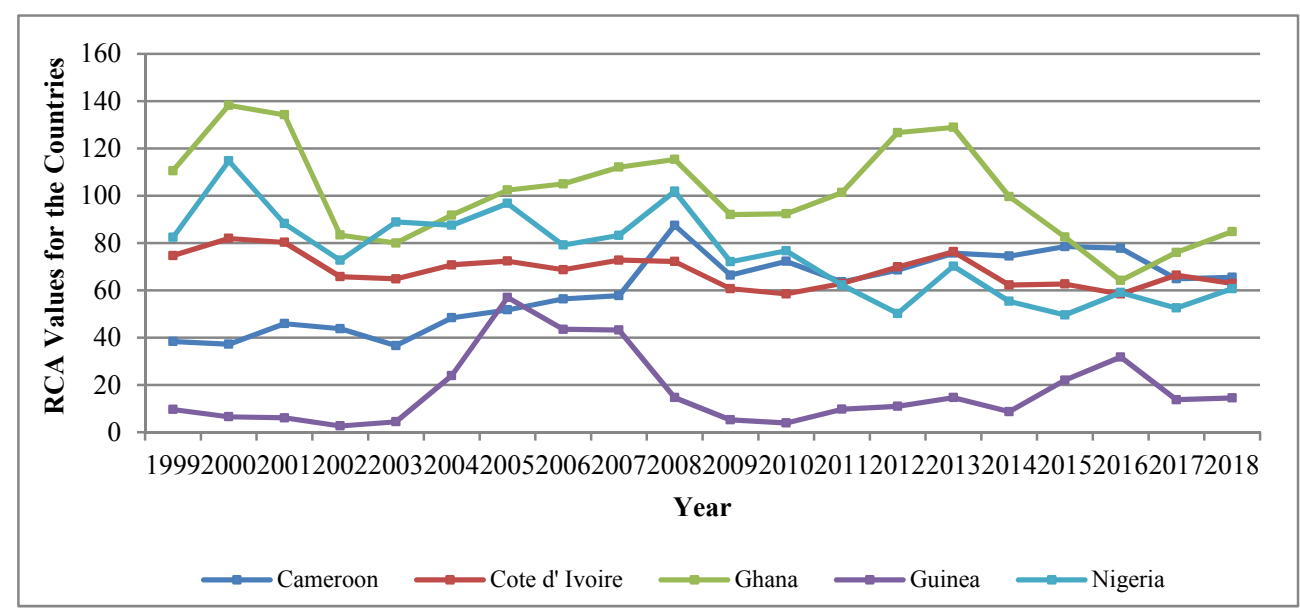

Figure 2. RCA for Cameroon, Cote d'Ivoire, Ghana, Guinea, and Nigeria from 1999-2018

Source: Authors Construct with data extracted from FAOSTAT. 
Table 1. RSCA for Cameroon, Cote d'Ivoire, Ghana, Guinea, and Nigeria from 1999-2018

\begin{tabular}{llllll}
\hline Year & Cameroon & Cote d'Ivoire & Ghana & Guinea & Nigeria \\
\hline 1999 & 0.949 & 0.974 & 0.982 & 0.812 & 0.976 \\
2000 & 0.948 & 0.976 & 0.986 & 0.734 & 0.983 \\
2001 & 0.957 & 0.975 & 0.985 & 0.718 & 0.976 \\
2002 & 0.955 & 0.97 & 0.976 & 0.457 & 0.973 \\
2003 & 0.947 & 0.97 & 0.975 & 0.631 & 0.978 \\
2004 & 0.959 & 0.972 & 0.978 & 0.92 & 0.977 \\
2005 & 0.962 & 0.973 & 0.981 & 0.966 & 0.98 \\
2006 & 0.965 & 0.971 & 0.981 & 0.955 & 0.975 \\
2007 & 0.966 & 0.973 & 0.982 & 0.955 & 0.976 \\
2008 & 0.977 & 0.973 & 0.983 & 0.872 & 0.981 \\
2009 & 0.97 & 0.968 & 0.978 & 0.678 & 0.973 \\
2010 & 0.973 & 0.966 & 0.979 & 0.593 & 0.974 \\
2011 & 0.969 & 0.969 & 0.98 & 0.814 & 0.968 \\
2012 & 0.971 & 0.972 & 0.984 & 0.833 & 0.961 \\
2013 & 0.974 & 0.974 & 0.985 & 0.872 & 0.972 \\
2014 & 0.974 & 0.968 & 0.98 & 0.794 & 0.965 \\
2015 & 0.975 & 0.969 & 0.976 & 0.913 & 0.96 \\
2016 & 0.975 & 0.966 & 0.969 & 0.939 & 0.967 \\
2017 & 0.971 & 0.97 & 0.974 & 0.864 & 0.963 \\
2018 & 0.971 & 0.969 & 0.977 & 0.871 & 0.968 \\
\hline
\end{tabular}

Source: Authors Computation with data extracted from FAOSTAT.

The findings of the study are not far different from those (David, 2013), who concluded that Ghana's cocoa bean export is highly competitive based on his analysis of RCA and RSCA values of cocoa beans, and processed cocoa exports which were computed with data from FAOSTAT. Ghana, therefore, needs to be proactive to maintain this stand, and this can only be guaranteed through the fashioning out of strategies to heal the wounds of the fluctuating production of Cocoa in Ghana.

\subsection{Determinants of Ghana's Cocoa Export}

In the literature, they are various factors that influence the export supply of agricultural commodities. Ranging from the point of cultivation, production, processing, trade, through to government policies and investment in the sector. Based on a careful study of the literature and an understanding of the Cocoa industry of Ghana, government policies, domestic producer price of Cocoa, the annual production volume of cocoa, the world consumer price of cocoa beans, and the exchange rate of the Ghana cedi to the United States dollar were chosen to predict their relationship with an export volume of cocoa beans from Ghana. However, government policy was not included in the regression equation because of the difficulty in expressing government policies in numbers.

To assess the significance and magnitude of the predictors of Cocoa export in Ghana, we first tried to identify the order of the series and a good estimator for our analysis. The Augmented Dickey-Fuller (ADF) test was done to test stationary. The results of the stationary test show that Ghana's export volume of cocoa and Ghana's annual cocoa production, based on intercept were stationary at $2^{\text {nd }}$ difference. Ghana's producer price and the exchange rate of Ghana cedi to the US dollar-based on-trend and intercept were stationary at the level and $2^{\text {nd }}$ difference respectively.

Grounded on the result of the stationary test, a multiple linear regression analysis was done using the Ordinary Least Squares (OLS) method. The result of the analysis is shown in Table 2 below. 
Table 2. Determinants of Cocoa export

\begin{tabular}{|c|c|c|c|c|}
\hline \multicolumn{5}{|c|}{ Dependent Variable: YCEX } \\
\hline \multicolumn{5}{|c|}{ Method: Least Squares } \\
\hline \multicolumn{5}{|c|}{ Date: $10 / 22 / 20$ Time: $07: 46$} \\
\hline \multicolumn{5}{|c|}{ Sample: 19792018} \\
\hline \multicolumn{5}{|c|}{ Included observations: 40} \\
\hline Variable & Coefficient & Std. Error & t-Statistic & Prob. \\
\hline $\mathrm{C}$ & 92298.98 & 55325.69 & 1.668284 & $0.1042 *$ \\
\hline GHCP & 0.649224 & 0.098908 & 6.563944 & $0.0000 * * *$ \\
\hline GPP & 0.000807 & 0.004428 & 0.182204 & 0.8565 \\
\hline WCP & -25.64398 & 28.19717 & -0.909452 & 0.3693 \\
\hline EXC_US\$_TO_GHC & 28566.97 & 86077.88 & 0.331874 & 0.7420 \\
\hline R-squared & 0.859213 & \multicolumn{2}{|c|}{ Mean dependent var } & 368481.1 \\
\hline Adjusted R-squared & 0.843123 & \multicolumn{2}{|c|}{ S.D. dependent var } & 185720.9 \\
\hline S.E. of regression & 73559.87 & \multicolumn{2}{|c|}{ Akaike info criterion } & 25.36606 \\
\hline Sum squared resid & $1.89 \mathrm{E}+11$ & \multicolumn{2}{|c|}{ Schwarz criterion } & 25.57717 \\
\hline Log-likelihood & -502.3211 & \multicolumn{2}{|c|}{ Hannan-Quinn criteria. } & 25.44239 \\
\hline F-statistic & 53.40042 & \multicolumn{2}{|c|}{ Durbin-Watson stat } & 2.542834 \\
\hline Prob(F-statistic) & 0.000000 & & & \\
\hline
\end{tabular}

Note. ***: $1 \%$; **: 5\%; *: 10\%.

The output is not a spurious regression hence worthy enough for predictions. This is based on the Durbin-Watson Stat (DW) estimate which is 2.542834 . This indicates the absence of serial autocorrelation. More so, the R-square value ( 0.859$)$ indicates that the model explains about $86 \%$ of variations in the export volume of cocoa from Ghana. Hence a good model.

It is clear from the results that there is a strong positive relationship between the total production of cocoa and export volumes. The results show that should there be a unit increase in the output of cocoa in Ghana, the quantity of cocoa beans export will be increased by $0.7 \%$. This is not surprising because for every rationale producer, once productivity is high, much of the produce is sold out to earn foreign exchange to enhance growth and development. Almost all the cocoa produced in Ghana are exported as raw cocoa beans. Cocoa export receipts are one of the largest in the non-oil exports from Ghana which earns for the country foreign exchange, government revenue, and employment. For the government, every good productivity calls for an increase in the export volume of cocoa to earn more revenue. However, The Cocoa Marketing Board turns to hoard cocoa when production rises but with a low global market price for cocoa.

This is done to ensure that cocoa products from Ghana will continue to attract premium value and to also prevent adding-up on the global market which turns to decrease world prices. The government of Ghana towards enhancing production and export is therefore supporting cocoa farmers with hybrid cocoa seeds, pesticides, and extension services to help cocoa farmers improve their yields.

Per the results of the analysis, there is a positive relationship between the producer price of cocoa and the export volume of cocoa. A unit increase in the domestic price of cocoa leads to a $0.0008 \%$ increase in exports. This is expected because cocoa producers take into consideration the domestic price of cocoa in Ghana in their production decision-making process. In Ghana, when the domestic price of cocoa is high, cocoa farmers are always eager to sell their cocoa to the licensed cocoa buyers who are mandated to buy cocoa from farmers and in turn sell it to the cocoa marketing board. This is because higher producer prices enable the farmers to invest much in the cocoa farms in anticipation of good yields. There is therefore a positive relationship between an increase in producer price and cocoa farmer's harvesting decisions.

According to Bulir (1998), "some farmers may decide not to collect their current crop if the offered producer prices are too low. This shows that producer price is fundamental in the supply decision of farmers, and setting it too low may have an unfavorable effect on export". This explains why the government keeps on reviewing the domestic price of cocoa upwards every year.

Stryker (1990) reiterates that successive falls in output and export could hugely be a result of low domestic producer prices paid to farmers. 
It is imperative from the results of the analysis that Ghana's cocoa industry is mindful of the interplay of the market forces of demand and supply. A unit reduction in the world price of cocoa beans triggers about -25.64398 decreases in the number of cocoa beans exported from Ghana. Every exporter aims to maximize optimum benefits and a decline in world prices also calls for withholding of cocoa beans because of the fear of running at a loss. Although there is always the issue of hold-ups when there is a fall in world price, Ghana keeps on increasing the volume of cocoa beans exported. This is because Ghana's cocoa is the world standard in terms of excellence which attracts a premium price, and so many increases could offset the deficits due to the falling global market price.

Because global prices are set based on the expected supply of cocoa for a given year, the government of Ghana always prefers to sell cocoa at a future price which is arrived at through the global commodity exchange bidding process. This price helps to hedge against fluctuating world prices. Since the government does not and cannot set the global market price for cocoa from Ghana.

There is a positive relationship between the exchange rate and the export volumes of cocoa beans in Ghana. When there is a slight appreciation in the exchange rate of the US\$ to GHC, there is an appreciation in the value of export earnings by 28566.97 in the export value of cocoa beans from Ghana. An increase in the exchange rate leads to the depreciation of the Ghana cedi, and this makes transnational exports cheaper hence an increase in the demand for exports. The Government of Ghana always takes advantage of the increased demand for the cocoa of Ghana to export large tons to receive a premium price which is quoted in the United States dollars.

The whole system and operation of Ghana's cocoa industry is exclusively the preserve of the Government of Ghana. The Ghana COCOBOD, which was established in 1947 as an agency working under the Ministry of Finance is mandated to monitor and regulate the operations of the cocoa industry in Ghana. The COCOBOD controls the export and internal marketing of cocoa beans, oversees agricultural research, hybridization of seeds, sale of seed to the farmers, quality control, and extension services to the farmers. This summarily, removing structural, institutional, legal and policy paucities that coerce economic agents to perform various marketing and other economic functions, explained the crucial role of government in the volume of cocoa beans exported from Ghana.

\section{Conclusion}

The study findings revealed that although the production volume of Ghana's cocoa is low compared with Cote d'Ivoire, Ghana is highly competitive in the export of cocoa beans. Ghana's cocoa bean export is strongly influenced by the volume of cocoa beans produced and the world consumer price of cocoa beans, the producer price of cocoa in Ghana, and government policies and programs. Ghana's RCA and RSCA figures show that Ghana has out-competed the other major producers and exporters of cocoa beans in the West African sub-region. This is because Ghana export very good quality cocoa beans and also as a result of the increasing government spending's to boost the sector performance. Ghana is famous for producing the best quality cocoa in the World and its whole marketing system, starting from stringent quality controls to an export monopoly, is geared towards maintaining this quality. However, Ghana needs to work on its ailing cocoa yields and production output. To increase Ghana's current production level and to grow its yield over the next years, Ghana's farmers would need to invest aggressively in new hybrid trees, use more fertilizer and insecticides to increase production, and also enhance the use of technology in cocoa farming.

Ghana risks losing this competitive urge if its current fluctuating production level is not resolved. Continues government spending in the sector, the motivation of cocoa farmers, the fight against the smuggling of cocoa, and increasing the number of cultivated fields could help Ghana to maintain its current good stand.

\section{Acknowledgements}

Data acquisition, data analyses, drafting, and revision of the manuscript was done by Alhassan Abukari.

The Conception, design, supervision, and approval of the manuscript for submission was done by Tan Cunfeng.

\section{References}

Abei, L. (2017). An analysis of the competitive performance of the Cameroonian cocoa industry (Master's thesis, Faculty of Economics and Manage, Stellenbosch University).

Balassa, B. (1965). Traded Liberalization and 'Revealed' Comparative Advantage. The Manchester School, 33(2), 99-123. https://doi.org/10.1111/j.1467-9957.1965.tb00050.x

Balassa, B. (1977). 'Revealed' Comparative Advantage Revisited: An Analysis of Relative Export Shares of the Industrial Countries, 1953-1971. The Manchester School, 45(4), 327-344. https://doi.org/10.1111/j.1467- 
9957.1977.tb00701.x

Bulir, A. (1998). The Price Incentive to Smuggle and the Cocoa Supply in Ghana, 1950-1996. IMF Working Papers, 98(88), 1. https://doi.org/10.5089/9781451851137.001

COCOBOD. (2012). 43rd Annual Report and Financial Statements for the Year Ended September 2012.

Coulombe, H., \& Wodon, Q. (2007). Poverty, livelihoods, and access to basic services in Ghana. CEM, Ghana. Retrieved from http://siteresources.worldbank.org/INTGHANA/Resources/CEM_poverty.pdf

Dalum, B., Laursen, K., \& Villumsen, G. (1998). Structural change in OECD export specialisation patterns: De-specialisation and "stickiness". International Review of Applied Economics, 12(3), 423-443. https://doi.org/10.1080/02692179800000017

Daramola, D. S. (2011). Empirical Investigations of Agricultural Export Trade in Nigeria (1975-2008): A Case Study of Cocoa and Palm Kernel. Economic and Financial Review, 49, 67-90.

David, B. (2013). Boansi Ghana competitiveness. Int. J. Agric Policy, 1, 236-254.

FAOSTAT. (2017). Agricultural Production Database. Food and Agricultural Organization of the United Nations, Rome. Retrieved from http://faostat.fao.org/site/703/default.aspx\#ancor

Garelli, S. (n.d.). Top Class Competitors: How Nations, Firms, and Individuals Succeed in the New World of Competitiveness. West Sussex, England: John Wiley \& Sons.

Gbetnkom, D., \& Khan, S. A. (2002). Determinants of Agricultural Exports: The Case of Cameroon (AERC Research Paper, 120). African Economic Research Consortium, Research Department.

Gilbert, C. L. (2009). Cocoa Market Liberalization in Retrospect. Review of Business and Economic, 3, 294-312.

Hinloopen, J., \& Van Marrewijk, C. (2001). On the Empirical Distribution of the Balassa Index. Weltwirtschaftliches Archiv, 137(1), 33-35. https://doi.org/10.1007/bf02707598

ICCO. (2012). Annual-Report-2012-2013-English-French-Spanish-Russian. Retrieved from https://www.scribd. com/document/343451692/Annual-Report-2012-2013-English-French-Spanish-Russian-pdf

IMF. (2015). Former Yugoslav Republic of Macedonia (Sigma Public Management Profiles 11). OECD Publishing.

Kolavalli, S., \& Vigneri, M. (2018). Growth through pricing policy: The case of cocoa in Ghana (pp. 1-6). Food and Agriculture Organization of the United Nations, Rome. Retrieved from http://www.fao.org/3/I8329 EN/i8329en.pdf

Kumar, N. R., Rai, A. B., \& Rai, M. (2008). Export of Cucumber and Gherkin from India: Performance, Destinations, Competitiveness, and Determinants. Agricultural Economics Research Review, 21(June), 130-138.

Lafay, J. (1992). The Measurement of Revealed Comparative Advantages. In M. G. Dagenais \& P. A. Muet (Eds.), International Trade Modeling. Chapman and Hall. https://doi.org/10.1007/978-1-4757-2150-8_10

Laursen, K. (2015). Revealed comparative advantage and the alternatives as measures of international specialization. Eurasian Business Review, 5(1), 99-115. https://doi.org/10.1007/s40821-015-0017-1

Liesner, H. H. (1958). The European Common Market and British Industry. The Economic Journal, 68(270), 302. https://doi.org/10.2307/2227597

Lundstedt, H. (2009). Cocoa is Ghana, Ghana is Cocoa-Evaluating Reforms of the Ghanaian Cocoa Sector.

Miteva-Kacarski, E. (2018). Revealed Comparative Advantage in Trade Between the Republic of Macedonia and Cefta 2006. Economic Review: Journal of Economics and Business, 16(1), 59-70.

Musila, J. W. (2004). The Common Market for Eastern and Southern African and Kenya's Export Trade. International Journal of Social Economics, 31(1-2), 67-77. https://doi.org/10.1108/03068290410515420

Ndubuto, I., Agwu, N., Nwaru, J., \& Imonikhe, G. (2010). Competitiveness and Determinants of Cocoa Exports from Ghana. International Journal of Agricultural Policy and Research, 1(9), 236-254.

Ngeno, K. (1996). Comparative Analysis of Economic Reform and Structural Adjustment Programme in Eastern Africa with Emphasis on Trade Policies (Technical Paper No. 20). SD Publication Series, Office of Sustainable Development Bureau for Africa.

OECD. (2013). Trade in Intermediate Goods and International Supply Chains in CEFTA. 
Osei-Assibey, E. (2015). Export Promotion in Ghana (p. 21). African Center for Economic Transformation, Ghana. Retrieved from http://includeplatform.net/wp-content/uploads/2015/03/GTF-Export-Promotion-inGhana-SR-formatted.compressed.pdf

Pitts, E., \& Lagnevik, M. (1998). What determines the food industry's competitiveness? In W. B. Traill. \& E. Pitts (Eds.), Competitiveness Food Industry. Springer.

Reiljan, J. (2000). Key Issues in Defining and Analysing the Competitiveness of a Country (No. 1). Faculty of Economics and Business Administration Working Paper Series from Faculty of Economics and Business Administration, University of Tartu, Estonia.

Rifin, A. (2013). Competitiveness of Indonesia's Cocoa Beans Export in the World Market. International Journal of Trade, Economics, and Finance, 4(5), 279-281. https://doi.org/10.7763/ijtef.2013.v4.301

Rondon, M., Ashitey, E., \& Union, E. (2012). Assessments of Commodity and Trade Issues by USDA Foreign Agricultural Services (GAIN Report Number GH1202). Global Agricultural Information Network (GAIN). Retrieved from https://www.fas.usda.gov/databases/global-agricultural-information-network-gain

Siggel, E. (2006). International competitiveness and comparative advantage: A survey and a proposal for measurement. Journal of Industry, Competition, and Trade, 6(2), 137-159. https://doi.org/10.1007/ s10842-006-8430-x

Siudek, T., \& Zawojska, A. (2018). Competitiveness in the economic concepts, theories, and competitiveness in the economic concepts, theories, and empirical research. Oeconomia, 13(1), 91-108.

Startienè, G., \& Remeikienè, R. (2014). Evaluation of Revealed Comparative Advantage of Lithuanian Industry in Global Markets. Procedia-Social and Behavioral Sciences, 110, 428-438. https://doi.org/10.1016/ j.sbspro.2013.12.887

Stryker, J. D. (1990). Trade, Exchange Rate, and Agricultural Pricing Policies in Ghana. World Bank Comparative Studies. Washing D.C., World Bank.

The World Bank Group, \& Agriculture Global Practice West Africa. (2017). Ghana: Agriculture sector policy note (p. 63).

Van Rooyen, J., \& Boonzaaier, J. (2016). Competitiveness in the Agribusiness Environment (from analysis to cooperative strategy development - A South Africa case study). 1st Annual Lecture of the Cooperative Central Bank, November 22, 2016, University of Cyprus.

Yeats, A. J. (1985). On the appropriate interpretation of the revealed comparative advantage index: Implications of a methodology based on industry sector analysis. Weltwirtschaftliches Archiv, 121(1), 61-73. https://doi.org/10.1007/BF02705840

\section{Copyrights}

Copyright for this article is retained by the author(s), with first publication rights granted to the journal.

This is an open-access article distributed under the terms and conditions of the Creative Commons Attribution license (http://creativecommons.org/licenses/by/4.0/). 